\title{
PIĘĆ WIEKÓW KOLBUSZOWEJ
}

Pozostańcie wierni doświadczeniu pokoleń, które żyły na tej ziemi z Bogiem w sercu i modlitwą na ustach...

Zachowujcie jak skarb największy to, co było źródłem duchowej siły waszych praojców

Jan Paweł II

Powiatowe miasto Kolbuszowa od lat stanowi silny ośrodek skupiający regionalistów, etnografów i miłośników ziemi rodzinnej. Zrzesza ich działające od połowy lat 50. XX wieku Regionalne Towarzystwo Kultury im. J. M. Goslara, które wspierają Muzeum Kultury Ludowej oraz Miejska i Powiatowa Biblioteka Publiczna w Kolbuszowej. Od szeregu już lat podejmują one rozmaite inicjatywy odkrywające i utrwalające w swoim środowisku tożsamość tej małej ojczyzny, jaka jest region kolbuszowski.

Taki charakter miała zorganizowana w dniu 10 października 2008 roku konferencja naukowa zatytułowana Pięć wieków Kolbuszowej 1500/1508 - 2008. $Z$ dziejów miasta i powiatu. Pomysłodawcą i współorganizatorem konferencji był ksiądz Sławomir Zych, pracownik naukowy Katolickiego Uniwersytetu Lubelskiego Jana Pawła II. Patronat nad tym wydarzeniem kulturalnym objęli: poseł na Sejm RP Zbigniew Chmielowiec, starosta kolbuszowski Józef Kardyś i burmistrz Kolbuszowej Jan Zuba. Patronatu medialnego podjęły się Ziemia Kolbuszowska i Niedziela Rzeszowska. Miejscem spotkania historyków, regionalistów, etnografów, a także zainteresowanych poruszaną tematyką mieszkańców Kolbuszowej i okolic była sala Czytelni im. dr. Kazimierza Skowrońskiego w Miejskiej i Powiatowej Bibliotece Publicznej w Kolbuszowej. W tym gronie znaleźli się też przedstawiciele miesięcznika społeczno-kulturalnego Kurier Sokołowski oraz Towarzystwa Miłośników Ziemi Sokołowskiej.

Otwarcie konferencji nastapiło o godzinie $8^{30}$. Dokonał tego dyrektor Miejskiej i Powiatowej Biblioteki Publicznej Andrzej Jagodziński, który powitał zebranych i wyraził radość z faktu, że podległa mu placówka może gościć w swych murach tylu naukowców, regionalistów i przedstawicieli mediów. Następnie głos 
zabrał ks. Sławomir Zych, który odczytał list biskupa Kazimierza Górnego wystosowany z okazji odbywającej się konferencji. Ordynariusz rzeszowski pogratulował organizatorom podjętej inicjatywy. Nawiązując do cytowanych na wstępie słów Jana Pawła II życzył, aby „konferencja z tak bogatym programem, miała także swój udział w przekazywaniu dziedzictwa minionych wieków młodemu pokoleniu, zaś młodzi, by umieli je podjąć i kontynuować”. Ostatnie słowa znalazły swych adresatów w osobach uczestniczących w konferencji uczniów kolbuszowskich szkół średnich. Kolejno z krótkim słowem powitalnym wystapili: starosta Józef Kardyś, burmistrz Jan Zuba i przedstawiciel posła Zbigniewa Chmielowca.

Pierwszą część wspólnego naukowego spotkania poprowadził przedstawiciel Regionalnego Towarzystwa Kultury im J. M. Goslara w Kolbuszowej mgr Wojciech Mroczka. Na wstępie głos zabrał doktorant w Podkarpackiej Szkole Wyższej im. bł. ks. W. Findysza w Jaśle mgr Karol Staniszewski, który w zastępstwie nieobecnego ks. dr. Jana Cebulaka odczytał jego referat na temat kierunków i celów rozwoju regionalnego Podkarpacia. Jako drugi wystapił doktorant Instytutu Badawczego Leśnictwa w Warszawie mgr Bartłomiej Peret reprezentujący na konferencji Nadleśnictwo w Kolbuszowej. Przedstawił on zebranym referat zatytułowany Różnorodność fauny i flory kolbuszowskich lasów. Warto dodać, że prelekcja ilustrowana była ciekawą prezentacją multimedialną. Jako trzeci głos zabrał dyrektor Muzeum Kultury Ludowej w Kolbuszowej mgr Jacek Bardan. Jego referat dotyczył herbów miasta i powiatu. Prelegent skupił się przede wszystkim na najstarszych odwzorowaniach godła Kolbuszowej, a także na pierwszych barwnych przedstawieniach godła, a później herbu miejskiego. Także i to wystapienie poparte było materiałem ilustracyjnym. Kolejno wystapił ks. dr Tomasz Moskal z Katolickiego Uniwersytetu Lubelskiego Jana Pawła II z referatem na temat dziejów parafii Kolbuszowa na tle historii dekanatu miechocińskiego od czasów najdawniejszych do roku 1772. Następnie mgr Wojciech Mroczka zreferował zagadnienia dotyczące nieznanych osad na ziemi kolbuszowskiej w okresie staropolskim. Kolejny prelegent - mgr Krzysztof Haptaś z Muzeum Regionalnego w Mielcu - wygłosił referat zatytułowany Biblioteka parafialna w Kolbuszowej w czasach staropolskich. Dziekan kolbuszowski i kustosz sanktuarium w Cmolasie ks. mgr Kazimierz Szkaradek zaznajomił zebranych z dziejami sanktuarium Przemienienia Pańskiego w Cmolasie. Tę część spotkania zamknęło wystapienie doktoranta Uniwersytetu Rzeszowskiego mgr. Pawła Michno na temat epigrafiki cmentarza parafialnego w Kolbuszowej. Referent przybliżył zgromadzonym zagadnienia związane z inskrypcjami i epitafiami nagrobnymi tejże nekropolii.

Po wystapieniach nastapiła półgodzinna przerwa, w czasie której w kuluarach przybyli wymieniać mogli poglądy na temat zaprezentowanych zagadnień, dyskutować z prelegentami lub przynajmniej pokrzepić nadwątlone siły. Organizatorzy zadbali bowiem nie tylko o ciepłe i zimne napoje, ale także o słodkie przekąski.

Druga część spotkania prowadzona była przez ks. dr. Tomasza Moskala. Jako pierwszy wystapił ks. mgr lic. Sławomir Zych, który przedstawił postać księcia Marcina Lubomirskiego i jego zagraniczne przypadki. Jak zaznaczył prelegent, ten związany z Kolbuszową księcia stał się pierwowzorem postaci Mikołaja Doświadczyńskiego z powieści Ignacego Krasickiego. Jako druga głos zabrała 
mgr Barbara Szafraniec z Regionalnego Towarzystwa Kultury im. J. M. Goslara w Kolbuszowej, która zaprezentowała referat zatytułowany Kolbuszowa w dobie autonomii galicyjskiej. Zebrany przez nią materiał zilustrowany został prezentacją multimedialną. Następną prelegentką była dr Jolanta Lenart z Uniwersytetu Rzeszowskiego. Jej wykład dotyczył szkolnictwa średniego w powiecie kolbuszowskim w latach 1944-1975. Sporo miejsca poświecono w nim Gimnazjum i Liceum w Sokołowie Małopolskim, które jako pierwsze w powiecie kolbuszowskim podjęło pracę po wycofaniu się wojsk niemieckich. Ciekawostką była niewątpliwe informacja o próbach uruchomienia szkoły średniej w niedalekim Raniżowie. Dr Paweł Sieradzki z Katolickiego Uniwersytetu Lubelskiego Jana Pawła II przybliżył słuchaczom kolbuszowski epizod rabacji galicyjskiej 1846 roku i jego echo w sieniawskich dobrach Czartoryskich. Kanwą rozważań stały się wspomnienia Karola Druziewicza, a miejscem, w którym rozegrały się przedstawione wydarzenia, była Werynia. Jako ostatni w tej części konferencji głos zabrał dr Grzegorz Zamoyski z Archiwum Państwowego w Rzeszowie, który zreferował zagadnienia dotyczace rady powiatowej w Kolbuszowej na przełomie XIX i XX wieku.

Ostatnią, poobiednią cześć obrad, poprowadził dr Paweł Sieradzki, a pierwszą prelegentką była dr Agnieszka Januszek-Sieradzka z Katolickiego Uniwersytetu Lubelskiego Jana Pawła II, która przedstawiła kwestie związane z lokacjami wsi w królewszczyznach Puszczy Sandomierskiej w czasach Zygmunta Augusta. Następnie Maciej Skowroński zaprezentował referat zatytułowany Życie społecznokulturalne w Kolbuszowej w latach 1772-1914. Jako trzeci głos zabrał przedstawiciel Miejskiej i Gminnej Biblioteki Publicznej w Sokołowie Małopolskim oraz Towarzystwa Miłośników Ziemi Sokołowskiej dr Bartosz Walicki. Problematyka wykładu osnuta była wokół zagadnień gospodarki i działalności społeczno-kulturalnej w Sokołowie w okresie przynależności do powiatu kolbuszowskiego. Z powodu ograniczeń czasowych, podobnie jak w przypadku wielu innych referatów, przedstawiona została tylko część przygotowanego materiału, to jest kwestie związane z gospodarką; zaprezentowano także jedynie część przygotowanej prezentacji multimedialnej stanowiącą ilustrację do poruszanej problematyki. W zastepstwie nieobecnego prof. dr. hab. Wacława Wierzbieńca z Uniwersytetu Rzeszowskiego referat na temat funkcjonowania gminy żydowskiej w Kolbuszowej odczytał dr Eugeniusz Lis. Kolejno wystąpił mgr Marian Piórek z Regionalnego Towarzystwa Kultury im. J. M. Goslara w Kolbuszowej, który w bardzo osobistych słowach podzielił się refleksjami na temat pracy szkół podstawowych powiatu kolbuszowskiego w pierwszych latach powojennych. Następnie nauczycielki Gimnazjum nr 2 im. Jana Pawła II w Kolbuszowej mgr Dorota Białek, mgr Anna Januszek i mgr Krystyna Styga przedstawiły zebranym prezentację multimedialną związaną z pracą szkoły i rolą jaką w tej pracy odgrywa postać patrona. Jako przedostatnia wystapiła doktorantka Uniwersytetu Kardynała Stefana Wyszyńskiego w Warszawie mgr Izabela Fac z wykładem na temat dziejów parafii pw. Św. Brata Alberta w Kolbuszowej. Spotkanie zamknął referat mgr Aliny Ziętek-Salwik zatytułowany Kolbuszowskie Liceum Ogólnoksztatcąe im. Janka Bytnara - szkoła wierna wartościom. 
Konferencję podsumował dyrektor kolbuszowskiej książnicy Andrzej Jagodziński. Zwrócił uwagę na fakt, że sesja stała się okazją do spotkania naukowców z różnych środowisk akademickich i regionalistów. Podkreślił, że takie wydarzenia kulturalne są bardzo potrzebne. Podziękował też ks. Sławomirowi Zychowi i autorom wystapień za ich intelektualny wysiłek i obecność. Jak zauważył: „,mieliśmy dziś przegląd tematyki od końca średniowiecza do współczesności. Było to bardzo pouczające. Mam nadzieję, że to spotkanie przyniesie pogłębioną refleksję na temat miasta i regionu oraz przyczyni się do wzrostu zainteresowania historią w wymiarze lokalnym". Dyrektor zapowiedział również ukazanie się drukiem materiałów konferencyjnych. W publikacji zamieszczone zostaną pełne teksty wystapień referentów. 